\title{
EUROPE 2020 AS AN INNOVATION CHALLENGE TO THE ŚWIĘTOKRZYSKIE VOIVODSHIP
}

\author{
Andrzej Pawlik ${ }^{1}$
}

\begin{abstract}
The article aims to explain the substance of Europe 2020 with a focus on innovation development projects and to assess the level of innovation in the Świętokrzyskie voivodship against the backdrop of other Polish voivodships. The article is composed of three parts. The first part presents the substance and assumptions of Europe 2020. Part two contains an analysis of the innovation of voivodships with a focus on the Świętokrzyskie voivodship (non-model method was used in this section). In part three, the emphasis is on presenting a forecast of the innovation of voivodships in 2020.
\end{abstract}

Key words: innovations, innovation, innovation potential, strategy.

\section{JEL Classification: 031}

\section{Introduction}

Undoubtedly, in the days of globalisation, technical and technological progress as well as of the information society, the transition to the knowledge-based economy becomes inevitable. Investment in innovation, research or workforce skills gains in importance as it increasingly influences economic development on a national and regional scale. The phenomenon of innovation is addressed ever-more frequently. Populations, enterprises, and countries, which develop and release an ability to generate innovation, succeed in economic and civilisational terms. The traditional factors of production, i.e. land, capital, and labour, continue to be important to economic activity but they yield to knowledge. Therefore, knowledge and information become the source of wealth and the most significant production factors. The Europe 2020 strategy, approved by the European Council in 2010, constitutes the European Union's response to various challenges: those resulting from ongoing globalisation, the breakthrough in the world economic order, the sovereign debt crisis, and the first signs of weakening social support for the European idea as exemplified by Brexit. The article aims to explain the substance of Europe 2020 with a focus on innovation development projects, to assess the level of innovation in the Swiętokrzyskie voivodship against the backdrop of other Polish voivodships, and to present a forecast of voivodship innovation in 2020 .

\section{The assumptions and objectives of Europe 2020}

The basis for the preparation of the Europe 2020 strategy was a summary and critical evaluation of the achievements and failures of the Lisbon Strategy ("Lisbon Strategy evaluation document, 2010"). Although the Lisbon Strategy did not attain a number of its goals, it was still valuable. It contributed to the setting of the European Union's development priorities in the long term and to the realisation of the need for structural reforms in the Member States. In June 2010, the European Council adopted the Europe 2020 strategy as a new long-term programme for the socio-economic development of the European Union for 2010-2020. According to the Council, none of the main development challenges identified in 2000, the reasons for preparing the Lisbon Strategy, lost any of its relevance. The current strategy constitutes the European Union's response to various socio-economic challenges. Recovering from the financial and economic crisis was treated as the first and short-term task of the new strategy. At the same time, the main policy assumption was that no immediate measures should result in a departure from actions for long-term structural reforms. Long-term problems such as globalisation, rising demand for limited resources and ageing populations are increasingly important.

'Europe 2020 - A strategy for smart, sustainable and inclusive growth' comprises three interconnected and mutually reinforcing thematic priorities (Communication, 2010). Those are consistent with the idea of sustainable growth based on three pillars: the economy, the environment, and society. They are as follows:

- Smart growth, i.e. developing an economy based on knowledge and innovation. Delivering on this priority requires improving the quality and attractiveness of European higher education, significant R\&D

\footnotetext{
Corresponding author:

${ }^{1}$ Jan Kochanowski University in Kielce, Poland.

E-mail: andrzejp1@vp.pl
} 
expenditure, bridging the gap between science and business needs, as well as promoting innovation and knowledge transfer throughout the Union or making maximum use of information and communication technologies;

- Sustainable growth, i.e. promoting a more resourceefficient, greener, and more competitive low-carbon economy;

- Inclusive growth, i.e. fostering a high-employment economy delivering social and territorial cohesion.

In contrast to the Lisbon Strategy, Europe 2020 contains no specified overarching goal. Instead of a single overarching aim, a package of five headline targets was adopted. They are important to all the Member States, regardless of their membership periods or differences in development levels. Those targets show where the European Union should be by 2020 and can be used to monitor progress towards the strategy implementation. The main targets are as follows (Communication, 2010):

- $75 \%$ of the population aged 20-64 should be employed;

$-3 \%$ of GDP should be invested in R\&D;

- the ' $20 / 20 / 20$ ' climate/energy targets should be met, which means reducing greenhouse gas emissions by at least $20 \%$ compared to 1990 levels, increasing the share of renewable energy sources in final energy consumption to $20 \%$, and a $20 \%$ increase in energy efficiency;

- the share of early school leavers should be reduced to $10 \%$ and the share of the population aged 30-34 having completed tertiary education should increase to $40 \%$;

- the number of people living below the national poverty lines should be reduced by at least 20 million.

The above-mentioned targets are interrelated and critical to the success of the strategy. For each Member State to be able to tailor the Europe 2020 strategy to its particular socio-economic situation, the Commission proposed that EU goals should be translated into national targets.

Europe 2020 contains a new implementation instrument in the form of flagship initiatives. Seven flagship initiatives were specified to catalyse progress under each priority theme (Communication, 2010):

- Innovation Union; making better use of science in practice;

- Youth on the move; enhancing the quality and attractiveness of European education systems at all levels; - A digital agenda for Europe; the EU's digital single market based on high-speed internet;

- Resource-efficient Europe; implementing the energy/ climate package and efficient use of resources in production and consumption;

- An industrial policy for the globalisation era; improving the competitiveness of the European industrial sector in the global market;

- An agenda for new skills and jobs; modernising labour markets and empowering people by developing their skills throughout the lifecycle, as well as increasing mobility;

- European platform against poverty; ensuring social and territorial cohesion such that people experiencing poverty and social exclusion are enabled to live in dignity and take an active part in society.

The implementation of those initiatives is a common priority, which involves actions at all levels of EU organisations, Member States, local and regional authorities. The degree of specification of actions within the seven initiatives varies widely, from initiatives with secured funding, e.g. 'A digital agenda for Europe', to those without indicated sources of financing, e.g. 'European platform against poverty'.

\section{The innovation of voivodships}

In considerations of the innovation of voivodships in Poland, it is necessary to first explain the concept of 'potential.' The notion of 'potential' is used in various sciences; in economic sciences, it is very important as an economic category determining the effectiveness and efficiency of any activity (Pawlik, 2012). It comes from the Latin word potentia, meaning 'capability', 'power.' It is derived from Aristotle, who distinguished between actuality and potentiality, i.e. something that does not yet exist but may materialise in certain conditions or if conditions change (Beczkiewicz, 1968). It is assumed that innovation potential can be defined as a set of interrelated elements of resources, which will be transformed into a new state thanks to an activity pursued. A resource is a quantitative and static category. It can be treated as a base for potential. Potential comprises resources necessary to the achievement of defined objectives of innovation activities. Innovation potential can be understood as an ability to generate, diffuse, and consume innovation by specific entities in a given area (Guzik 2003). The innovation potential of a region also includes anything the region can use - natural resources, man-made resources, intellectual resources (Zarządzanie działalnością innowacyjną, 2010).

Innovation potential constitutes the sum of economic potential, scientific potential, technology and innovations potential, as well as of intellectual potential. The aforementionedcomponentsarecloselyrelated.Intellectual potential reinforces scientific potential, technology and economic potentials, it also creates the potential for itself. Scientific potential reinforces intellectual, technology, and economic potentials. Technology potential reinforces intellectual, technology, and economic potentials, whereas economic potential reinforces intellectual, scientific, and technology potentials. Each potential can pose a barrier to the growth of all the other four potentials. Each of them creates the potential for itself (Zarządzanie działalnością innowacyjną, 2010).

Studies show that the economies of Polish voivodships are not based on potentials necessary to their development. 
The analysis conducted used selected characteristics reflecting innovation. The characteristics were selected so that they should reflect the following (Gorzelak, 1979): relevance to the phenomena under analysis, the unambiguity and precision of definition, the exhaustiveness of the scope of the phenomenon concerned, the logic of interrelations, maintaining comparability of the representation of sub-phenomena, measurability i.e. the possibility to numerically express the levels of characteristics - and the availability and completeness of statistical information for all objects (Śmiłowska, 1997). In the examination, preference was given to variables with relative values since the inclusion of a number of metrics in absolute values could lead to misrepresentation (Młodak, 2006). The analysis conducted used selected characteristics reflecting innovation. Those were divided into four components - groups characterising different areas adding up to describe innovation.

Withinthecomponentsdefined,statisticalcharacteristics were determined so as to interpret innovation in the description of the component concerned. Due to the subject-matter of the analysis, the main criterion for the selection of characteristics to be studied further was relevance, i.e. the inclusion of variables representing in substance the phenomenon covered (Pawlik, 2014). From the point of view of the research structure, the principle followed was the substantive relevance to specific components defined for the innovation of voivodships. The selection of variables was based on the available literature and various research approaches. Forty-six statistical characteristics were selected to describe the innovation of individual voivodships and divided into four groups: economic potential, scientific potential, technology and innovations potential, as well as intellectual potential. All of them combined interpreted innovation potential. In order to ensure relevant and disjoint sets, the analysed characteristics were appropriately verified to determine variation (the coefficient of variation was calculated (Dziekański, 2015)) and the correlation between all the variables ${ }^{1}$. The number of statistical characteristics was largely limited by their availability. As the source material, the analysis used data from the Local Data Bank (Bank Danych Lokalnych) of the Polish Central Statistical Office (GUS) for 2002, 2009, 2016 and a forecast for 2020. Unfortunately, the limited size of the article prevents a full presentation of the characteristics and the course of the study.

On the basis of the 46 characteristics - variables, the non-model method was used to calculate composite indices for each of the four groups (economic potential, scientific potential, technology and innovations potential, as well as intellectual potential), followed by the computation of the overall composite index (the arithmetic mean) in 2002, 2009, 2016 and, based on the result obtained, a forecast for 2020 - Table 1.

\footnotetext{
1 The study adopted the maximum threshold (limit) of correlation at $\mathrm{R}=0.5$
}

Table 1

Innovation potential of voivodships the overall composite index in 2002, 2009, 2016 and a forecast for $\mathbf{2 0 2 0}$

\begin{tabular}{|l|l|l|l|l|}
\hline \multicolumn{1}{|c|}{ Voivodship } & 2002 & 2009 & 2016 & 2020 \\
\hline Dolnośląskie & 0.309 & 0.496 & 0.683 & 0.790 \\
\hline Kujawsko-Pomorskie & 0.178 & 0.314 & 0.450 & 0.529 \\
\hline Lubelskie & 0.209 & 0.330 & 0.450 & 0.519 \\
\hline Lubuskie & 0.128 & 0.224 & 0.319 & 0.334 \\
\hline Łódzkie & 0.253 & 0.431 & 0.609 & 0.711 \\
\hline Małopolskie & 0.336 & 0.516 & 0.695 & 0.798 \\
\hline Mazowieckie & 0.643 & 0.937 & 1.230 & 1.399 \\
\hline Opolskie & 0.129 & 0.255 & 0.380 & 0.453 \\
\hline Podkarpackie & 0.159 & 0.273 & 0.387 & 0.452 \\
\hline Podlaskie & 0.152 & 0.245 & 0.337 & 0.391 \\
\hline Pomorskie & 0.211 & 0.360 & 0.508 & 0.594 \\
\hline Śląskie & 0.365 & 0.578 & 0.790 & 0.912 \\
\hline Świętokrzyskie & 0.141 & 0.256 & 0.370 & 0.437 \\
\hline Warmińsko-Mazurskie & 0.137 & 0.227 & 0.316 & 0.368 \\
\hline Wielkopolskie & 0.286 & 0.472 & 0.659 & 0.766 \\
\hline Zachodniopomorskie & 0.215 & 0.304 & 0.392 & 0.443 \\
\hline
\end{tabular}

Source: Own calculations based on the gathered statistical database containing 46 variables for particular voivodships in 2002, 2009, 2016 on the basis of the Local Data Bank, GUS, and forecasts for 2020, A. Pawlik, Dystans innowacyjny województw w roku 2016, Wydawnictwo Uniwersytetu Jana Kochanowskiego, Kielce 2014, p. 105.

The composite indices of the innovation potential of particular voivodships are presented in alphabetical order of the voivodships. It is important to consider not only the rank of a voivodship but also the index value obtained by that voivodship in the subsequent years of the study. The innovation potential of voivodships was defined with the use of the overall index including the four potentials presented before. The highest overall indices - determining the innovation potential of voivodships reflecting all the four components in 2002, 2009, 2016 - characterised the following voivodships: Mazowieckie (0.643; 0.937 and 1.230$)$, Śląskie (0.365; 0.578 and 0.790$)$ and Małopolskie (0.336; 0.516 and 0.695). In 2002, the lowest overall indices of innovation potential were obtained for the following voivodships: Lubuskie (0.128), Opolskie (0.129) and WarmińskoMazurskie (0.137). In 2009 and 2016, the group with the weakest innovation potential was as follows: Lubuskie (0.224 and 0.319), Warmińsko-Mazurskie (0.227 and 0.316), Podlaskie (0.245 and 0.337), Opolskie (0.255 and 0.380) and Świętokrzyskie $(0.256$ and 0.370$)$. It must be emphasised that the rank of voivodships in specific potentials translated into the final rank in the overall innovation potential. The final ranks in terms of innovation potential of the weakest voivodships were determined, inter alia, by their ranks in technology and innovations potential. For example, the high index within that component of the Świętokrzyskie voivodship was 
ultimately translated into the $13^{\text {th }}$ place of the Świętokrzyskie voivodship in terms of innovation in 2016. The Świętokrzyskie voivodship ranks low in scientific potential and intellectual potential. Thanks to its technology and innovations potential, the Świętokrzyskie voivodship ranked $13^{\text {th }}$ in terms of overall innovation potential. The data contained in Tables 1 and 2 unambiguously indicate the average level of the innovation of voivodships. The ranks but primarily the index values for the Świętokrzyskie voivodship in specific years $(0.141 ; 0.256$ and 0.370$)$ are somewhat alarming. High values of indices reflecting economic potential, scientific potential, technology and innovations potential, as well as intellectual potential determined the final ranks of voivodships in terms of innovation potential. It must be stressed that the ranks of voivodships in subsequent potentials translated into the final position in the overall innovation potential - the innovation index. Therefore, considering innovation potential, the Świętokrzyskie voivodship should primarily develop economic potential, scientific potential, technology potential, and intellectual potential. In the context of the Europe 2020 strategy, the goal of a $3 \%$ share of R\&D expenditure in GDP is unattainable for Poland, all the more for the Świętokrzyskie voivodship. Reducing greenhouse gas emissions, increasing the share of renewable energy sources, and improving energy efficiency will be also difficult to achieve; those objectives pose a challenge to Poland and an enormous one to the Świętokrzyskie voivodship. The targets of reducing the share of early school leavers, increasing the share of persons having completed tertiary education, and lowering the number of people living below the national poverty line are attainable in both Poland and the Świętokrzyskie voivodship by 2020.

\section{The forecast for the innovation of voivodships in 2020}

By analysing the time series composed of observations at three points in time (the composite indices in 2002, 2009, and 2016), the innovation potential of voivodships was forecast for 2020 (Table 2). The publication limitations prevent a more detailed discussion of the methodology contained in the author's book (Pawlik, 2014).

Figure 1 presents the forecast innovation potential of voivodships in 2020. In 2020, the innovation potential will increase in all the voivodships, especially in the Mazowieckie voivodship, the centre and the top performer in terms of growth in innovation potential. The Śląskie will also speed up, being an unquestionable vice-leader, thanks to increased economic, technology

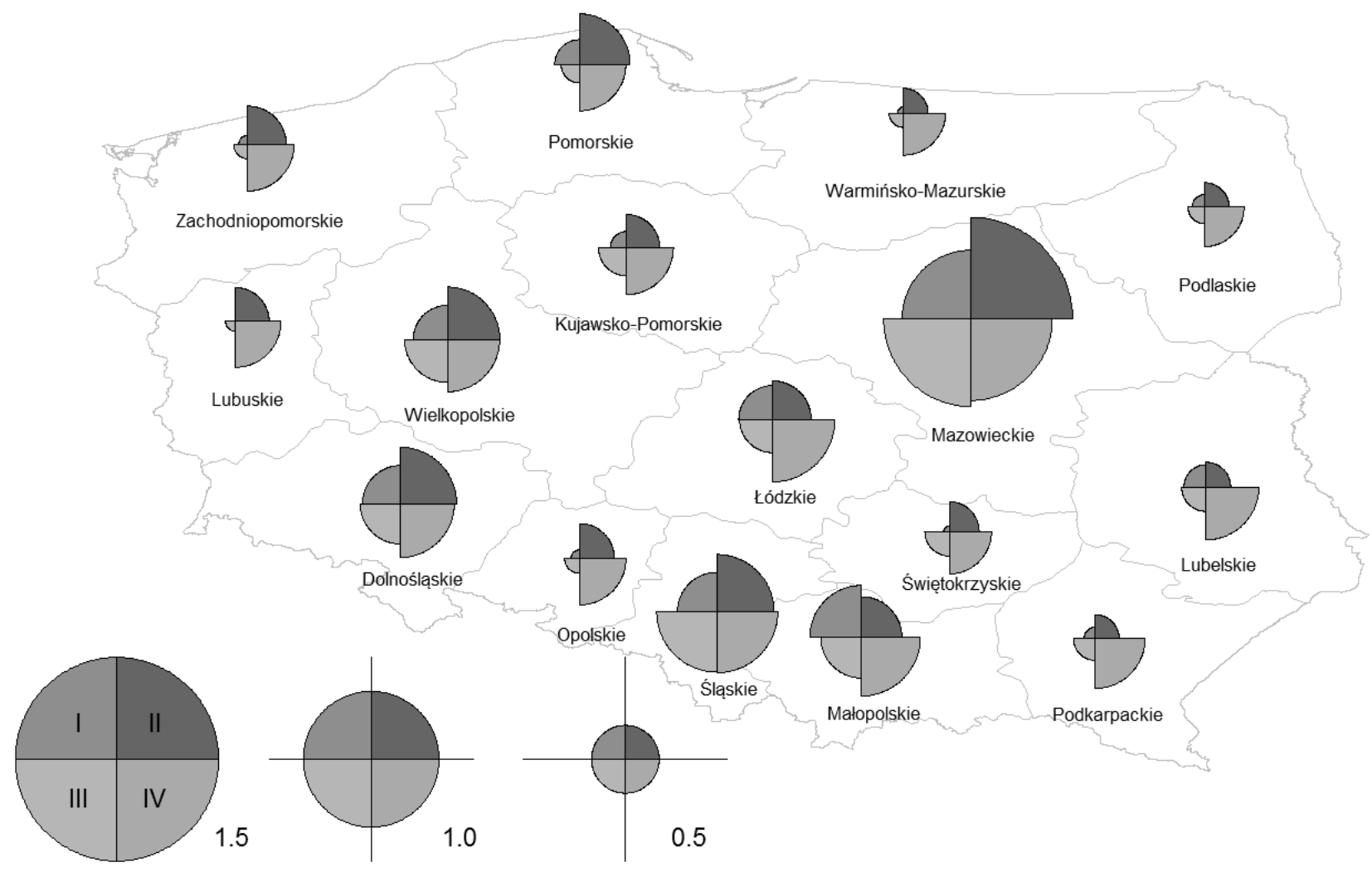

Figure 1. Forecast innovation potential of voivodships in 2020, I - economic potential, II - scientific potential, III - technology and innovations potential, IV - intellectual potential

Source: own study based on the composite index values for individual potentials 
Table 2

\section{Forecast composite indices of potential in 2020}

\begin{tabular}{|l|c|c|c|c|}
\hline & EP & SP & TP & IP \\
\hline Dolnośląskie & 0.9862 & 0.5969 & 0.6793 & 0.8990 \\
\hline Kujawsko-Pomorskie & 0.5800 & 0.2621 & 0.4788 & 0.7936 \\
\hline Lubelskie & 0.4397 & 0.3501 & 0.4054 & 0.8827 \\
\hline Lubuskie & 0.6023 & -0.0361 & 0.1532 & 0.7786 \\
\hline Łódzkie & 0.6720 & 0.5501 & 0.5490 & 1.0718 \\
\hline Małopolskie & 0.7007 & 0.8274 & 0.6687 & 0.9964 \\
\hline Mazowieckie & 1.7515 & 1.0192 & 1.4530 & 1.3707 \\
\hline Opolskie & 0.6192 & 0.1417 & 0.2469 & 0.8023 \\
\hline Podkarpackie & 0.4223 & 0.1715 & 0.3568 & 0.8592 \\
\hline Podlaskie & 0.4279 & 0.1957 & 0.2771 & 0.6619 \\
\hline Pomorskie & 0.8883 & 0.4005 & 0.2860 & 0.8001 \\
\hline Śląskie & 0.9908 & 0.5877 & 1.0295 & 1.0402 \\
\hline Świętokrzyskie & 0.5331 & 0.0699 & 0.4238 & 0.7195 \\
\hline Warmińsko-Mazurskie & 0.4462 & 0.0911 & 0.2232 & 0.7116 \\
\hline Wielkopolskie & 0.9092 & 0.5375 & 0.7301 & 0.8861 \\
\hline Zachodniopomorskie & 0.6725 & 0.0936 & 0.2219 & 0.7829 \\
\hline
\end{tabular}

Source: Own calculations. EP - economic potential, SP - scientific potential, TP - technology and innovations potential, IP - intellectual potential

and innovations and intellectual potentials. The Małopolskie voivodship will rank third, with strong scientific potential and intellectual potential. Due to growth in economic and intellectual potentials, the Dolnośląskie voivodship will be ranked fourth. The Dolnośląskie voivodship will be slightly ahead of the Wielkopolskie voivodship, also characterised by significant dynamics of economic and intellectual potentials. Fierce competition between voivodships may contribute to reducing differences in the innovation potential of the following voivodships: Małopolskie, Dolnośląskie, and Wielkopolskie, followed by the Łódzkie voivodship with the strong intellectual potential. To recapitulate the study conducted, it must be pointed out that the presented indices for 10 voivodships basically do not exceed 0.500 , which indicates weak positions of voivodships in terms of innovation.

\section{Conclusion}

In the Europe 2020 project, the European Union rightly stresses the importance of knowledge and innovation as drivers of competitiveness. The position of Polish voivodships, particularly against the backdrop of European regions, confirms the need for taking appropriate measures (Hollanders, 2016). Therefore, the European Commission proposes a new cohesion policy to strictly link access to structural funds and cohesion funds with the implementation of structural reforms promoting economic growth. In accordance with the goals of Europe 2020, the European Commission proposes to significantly increase investment in $R \& D$ and innovation, education, infrastructure, and energy performance in the 2014-2020 budget. For example, appropriations in the amount of EUR 50 billion within the Connecting Europe Facility will be used to finance major projects concerning the development of ICT, cross-border transport and improving energy efficiency. The Facility will bridge missing links between Europe's major economic infrastructures, e.g. cross-border investments necessary to the transmission of energy across Europe.

As demonstrated by the study, in 2020, Polish voivodships, catching up with the strongest and clearly leading the Mazowieckie voivodship, will be characterised by average attractiveness to residents and investors in terms of potential. The development of particular groups of the forecast innovation potential of voivodships (Table 2 and Figure 1) shows a distinct advantage of the Mazowieckie in comparison with the other voivodships; furthermore, it follows from the investigation that:

1) economic potential becomes the basis for innovation potential;

2 ) the greatest innovation potential will continue to characterise the Mazowieckie voivodship, still significantly ahead of the other voivodships;

3) the least innovation potential will be observed in the following voivodships: Lubuskie, WarmińskoMazurskie, and Podlaskie. The above-mentioned voivodships also had the lowest potentials in 2002, 2009, and 2016;

4) only voivodships with strongly developed economic potential such as the Pomorskie voivodship are likely to significantly increase their innovation potential;

5) special development programmes should be targeted at the Lubuskie, Warmińsko-Mazurskie, and Świętokrzyskie voivodships;

6) the analysis of developments in the innovation potential of the voivodships covered shows many new challenges to the regional policy by 2020 and for the following years.

By 2020, all the voivodships will experience an improved economic situation but not all of them will grow at the same rate. The index analysis results corroborated significant intra-regional differentiation in the level of development and a strong concentration of activity in the Mazowieckie voivodship. Importantly, however, the key role in development will be played by innovation potential.

The Europe 2020 strategy represents the European Union's ambitious response to the aforementioned challenges and constitutes one of the most advanced modernisation programmes in the history of European integration. In addition, the strategy poses an enormous challenge to Poland, in particular, to the Świętokrzyskie voivodship, in terms of strengthening research potential and improving innovation. 


\section{References:}

Beczkiewicz, Z. (1968). Ekonomika obrony narodowej. MON, Warszawa.

Communication from the Commission Europe 2020 (2010). A strategy for smart, sustainable and inclusive growth. COM 2020 final, 3.03.2010, Brussels.

Dziekański, P. (2015). Wykorzystanie wskaźnika syntetycznego do oceny poziomu rozwoju samorządu na przykładzie gmin wiejskich województwa świętokrzyskiego, (in:) Owsiak, S. (ed.). Determinanty rozwoju polski; Finanse publiczne, PTE, Warszawa.

Gorzelak, G. (1979). Dobór zmiennych w statystycznej analizie porównawczej. Wiadomości Statystyczne, z. 3, PTS, GUS, Warszawa.

Guzik, R. (2003). Przestrzenne zróżnicowanie potencjału innowacyjnego w Polsce, (in:) Górzyński, M., \& Woodward, R., (eds.). Innowacyjność polskiej gospodarki, Zeszyty Innowacyjne, no. 2.

Hollanders, H., Tarantola, S., \& Loschky, A. (2016). Regional Innovation Scoreboard (RIS). Maastricht University. Retrieved from http://www.merit.unu.edu (accessed August, 31, 2018).

Lisbon Strategy evaluation document, European Commission, Commission StaffWorking Document, SEC(2010)114, final, 2.2.2010, Brussels. Retrieved from: http://ec.europa.eu/transparency/regdoc/rep/2/2010/EN/SEC-2010114-F1-EN-MAIN-PART-1.PDF

Młodak, A. (2006). Analiza taksonomiczna w statystyce regionalnej. Difin, Warszawa.

Pawlik, A. (2012). Potencjat innowacyjny w rozwoju regionalnym. Wydawnictwo Uniwersytetu Jana Kochanowskiego, Kielce.

Pawlik,A. (2014). Dystans innowacyjny województww roku 2016. Wydawnictwo Uniwersytetu Jana Kochanowskiego, Kielce.

Śmiłowska, T. (1997). Statystyczna analiza poziomu życia ludności Polski $w$ ujęciu przestrzennym. Studia i Prace Zakładu Badań Statystyczno-Ekonomicznych, GUS i PAN, z. 247, Warszawa.

Zarządzanie działalnościa innowacyjna (2010). ed. Białoń L., Wydawnictwo Placet, Warszawa. 